\title{
Inquiry Learning Models to Improve Students' Science Process Skills in Plant Anatomy Courses
}

\author{
Kasmiruddin $^{1,2, *}$ and Nopriyeni ${ }^{1}$ \\ ${ }^{1}$ Department of Biology Education, Muhammadiyah University of Bengkulu, Indonesia \\ ${ }^{2}$ Education Doctoral Study Program, Faculty of Teacher Training and Education, University Bengkulu \\ *Corresponding author. Email: kasmirgogo@gmail.com
}

\begin{abstract}
This study aims to determine the improvement of students' science process skills in the plant anatomy course by using an inquiry learning model. The method used in this research is a quasi experiment. The research design used was the pre-test post test control group design. The sample in this study were all students in semester III with a total of 65 people divided into 2 classes, 1 class as the experimental class and 1 class as the control class. Data collection was conducted using instruments in the form of test descriptions and observation sheets. The data analysis technique used the One Way Anova test. The results showed an increase in student science process skills using the inquiry learning model.
\end{abstract}

Keywords: Inquiry learning models, Science process skills, Students, Plant anatomy.

\section{INTRODUCTION}

Regulation of the Minister of National Education (Permendiknas) No. 22 of 2006 states that science learning should be carried out by scientific inquiry to build the ability to think, work and have a scientific attitude and communicate it as an important aspect of life skills. Inquiry Model is a series of learning activities that maximally involves all students' abilities which aim to seek and investigate systematically, critically, logically, and analytically so that they can formulate their own findings confidently [1].

Inquiry is a learning model that has an important role in building a constructivist learning paradigm that emphasizes student learning activeness. The application of an inquiry model based on constructivist theory makes students gain direct experience and build their own knowledge [2]. Inquiry learning can motivate students to experiment so that they have learning skills in finding a principle of learning material based on the problems posed and the learning atmosphere becomes more enjoyable because in the learning process students are actively involved in it [3].

Inquiry learning is learning that emphasizes the intellectual development of children. The advantages of the inquiry learning process are (1) it encourages relationships to grow in cooperation, (2) provides fast feedback, (3) provides confirmation of time on assignments, (4) deals with many predictions, and (5) is responsive to differences in talents and learning methods. [4].

From the description above it can be concluded that inquiry learning does not only develop intellectual abilities but all existing potential, including emotional development and inquiry skills, which is a process that starts from formulating problems, formulating hypotheses, collecting data and making conclusions. Process skills are all learning activities in the teaching and learning process in motion and action to discover, develop facts, concepts and foster and develop attitudes and values [5]. Process skills consist of a number of skills that cannot be separated from each other, but there is a special emphasis in each of these skills which includes: Observing (observation), Grouping (classification) Interpreting (inference), Predicting (prediction), Implementing (application ), Communicating, Asking Questions, Conducting Experiments [6].

Science process skills are skills that are obtained from the training of basic mental, physical and social abilities as a driving force for higher abilities. The approach to process skills is described in teaching and learning activities paying attention to the development of knowledge of attitudes, values and skills. Process skills aim to improve the ability of students to realize, understand and master a series of activities related to the learning outcomes that students have achieved. The series of activities in question are activities to observe, classify, interpret, 
predict, implement, plan research, and communicate [7].

\section{BACKGROUND}

Improvement and development of student science process skills needs to be done in learning. Cognitive skills such as logical thinking, reasoning and problem solving all rely on students' science process skills [8]. In the context of science learning, it is explained that inquiry learning can facilitate students to develop new skills, manipulation and process skills, communication skills, creative skills, and student attitudes. Then another view of learning with an inquiry approach can involve students actively using scientific processes and scientific and creative skills as they find answers to the questions posed [9]. In this case, learning is designed by exposing students to contextual problems related to lecture materials so that students know why they are learning then identify and collect information from source books [10].

Scientific knowledge that comes from science process skills is able to solve problems in society [11]. Students who master science process skills can do the concepts they want to understand on their own. Science process skills train students to collect information, analyze information, and apply this information in a broader context in their lives. Students who master science process skills are able to work logically and systematically. The abilities obtained can also be transferred to other fields of science. Once students can make graphics, for example, the learning outcomes can be applied to other fields of science [6].

Science process skills are beneficial for students, science process skills can be used to solve learning problems and students' daily lives [12]. Students who master science process skills can carry out simple scientific investigation activities to find out for themselves the concepts they want to understand. Science process skills benefit students. Based on the opinion of these experts, it can be concluded that the application of science process skills requires physical and mental-intellectual involvement of students. It can be used to train and develop students' intellectual skills or thinking abilities. In addition, it also develops scientific attitudes and students' abilities to discover and develop facts, concepts, and principles of science or knowledge.

The scientific approach has relevance with authentic assessment where assessment is an important part of learning. Learning is not only result oriented but also process oriented. Science process skills are basic skills and integrated skills. Student process skills can be developed from direct experience, learning that accommodates direct experience is inquiry learning [13]. Learning activities aim to foster students' ability to use process skills by formulating questions that lead to investigative activities, formulating hypotheses, conducting experiments, collecting data, processing data, evaluating and communicating their findings in the learning community. Setyosari [14] stated that effective learning is the unity of quality learning. Learning is said to be effective if the learning objectives are achieved [15].

Increasing science process skills can be done through the application of inquiry methods in learning [16]. The same thing also states that students' abilities in inquiry can be trained through the application of inquiry learning [17]. Thus, inquiry activity is indispensable as an effort to optimize the involvement of students 'direct experience in the learning process. This is supported by research of Ayuningtyas [18] showing that the students' science process skills achieved the good category with an average score of 83.31. The conclusion is that students' science process skills can be improved by using guided inquiry models in the ongoing learning process. Then the study [15] showed that the increase in science process skills of students with different knowledge, the application of inquiry learning was most effective at level 3, students with high and low initial knowledge obtained higher gain scores from the application of inquiry learning levels 2 and level 4 and research. Putri [19] from the results of the study showed that the implementation of the lesson plan in cycle I to cycle II with the good category was very good and student learning outcomes had increased from cycle I of $41.46 \%$ which completed to $80.48 \%$ then those who were complete in cycle II could declared classically complete. The conclusion is that the guided inquiry learning model can improve students' science process skills and student learning outcomes class VIII C of SMP Negeri Banjarmasin.

Plant anatomy is a compulsory subject in the biology education program of the FKIP Muhammadiyah University of Bengkulu. The two combinations of aspects of plant anatomy material with the application of inquiry models are seen as effective in helping students to think more creatively in mastering the basic concepts of plant anatomy and of course further improving students' science process skills, this is supported by the results of research [20], which states that there is an influence of the learning model. laboratory inquiry into students' science process skills.

Based on the results of preliminary observations of the Plant Anatomy lecture in the biology education study program at FKIP Muhammadiyah Bengkulu University, lecturers have 
provided opportunities for students to develop their skills by applying the discussion method with the addition of power point media aids and book references as a learning resource, which is the method. This discussion is a method commonly used in ongoing lectures, so it can be said to be a conventional learning model. However, this learning has not been felt to be able to increase the ability of students' science process skills in this subject.

From the data obtained during observation, the average scores of all students in the plant anatomy subject were 69.50 and 68 (3rd semester student scores). Based on the background and observational data, it is necessary to carry out research to improve students' science process skills in the Plant Anatomy course by using an inquiry learning model.

\section{RESEARCH METHOD}

\subsection{Research Preparation}

\subsubsection{Preparation phase}

At this stage the researcher examines the sub-topic of root anatomy as teaching material, followed by making SAP, research instruments and student worksheets.

\subsubsection{Implementation Stage}

The implementation stage begins with giving a pretest. During the learning process, the researcher acts as a lecturer in plant anatomy by applying inquiry learning models and conventional learning. Furthermore, all data collected were analyzed and given conclusions.

\subsection{Research Design}

This research is a quasi-experimental research type, to determine the improvement of students' science process skills using inquiry-based learning models, and those using conventional learning models.

The design used in this study was the pretest posttest design, which was divided into two groups, namely the inquiry learning model group and the conventional learning group. For the treatment group, namely the class that applied the inquiry model learning $\left(\mathrm{X}_{1}\right)$ while the control group applied conventional learning $\left(\mathrm{X}_{0}\right)$, after which the two groups were given a test in the form of knowledge about plant anatomy both the same pretest $\left(\mathrm{O}_{1}\right)$ and the same posttest $\left(\mathrm{O}_{2}\right)$, and then tested One Line Anava. The design table is as follows:

Table. 1 Pre-test-post-test design for experimental and control class

\begin{tabular}{|l|c|c|c|}
\hline \multicolumn{1}{|c|}{ Group } & Pretest & Treatment & Postest \\
\hline A (eksperimen) & $\mathrm{O}_{1}$ & $\mathrm{X}_{1}$ & $\mathrm{O}_{2}$ \\
\hline B (Control) & $\mathrm{O}_{1}$ & $\mathrm{X}_{0}$ & $\mathrm{O}_{2}$ \\
\hline
\end{tabular}

Information :

$\mathrm{O}_{1}$ : Pretest

$\mathrm{X}_{1}$ : learning with the Inquiry model

\subsection{Data Analysis}

\subsubsection{Test Prerequisite Analysis}

\subsubsection{Normality Test}

The normality test is used to test whether the data in the study were obtained from a normally distributed population or not. In this study, the normality test used SPSS, namely the One Sample KolmogorovSmirnov test.

The steps are as follows:

1. Determine the hypothesis.

H0: The sample is not normally distributed

H1: The sample is normally distributed

2. The test decision.

$\mathrm{H} 0$ is rejected if $\mathrm{p}$ value $<0.05$ or not rejected if $\mathrm{p}$ value $>0.05$

3.3.1.2 Homogeneity Test
$\mathrm{X}_{0}$ : Conventional Learning

$\mathrm{O}_{2}$ : Postest

If a normality test gives an indication that the research result data is normally distributed, then the homogeneity test of this research sample is carried out. This test is intended to test the similarity of population variances that are normally distributed, the homogeneity test uses the SPSS program through the Levene Statistic test. If the probability value is> 0.05 then the data comes from a population with the same or homogeneous variance.

\subsubsection{Hypothesis Testing}

a. The data obtained will be used one way ANOVA test (One Way ANOVA) and statistical analysis assisted by IBM SPSS software for windows and Microsoft Excel. If there are significant differences, continue with the LSD or Tukey test in determining: 
- Differences in science process skills in the inquiry learning model and conventional models

\section{RESULTS AND DISCUSSION}

\subsection{Research Results}

\subsubsection{Description of Research Implementation}

This research is a quasi-experimental research. This research was conducted on the third semester students of the biology education study program FKIP Biology, Muhammadiyah University of Bengkulu. The subject population consisted of two classes, as the research sample two classes were determined to have relatively the same academic ability / homogeneous through the pretest. The material chosen in this study was plant root anatomy. After the initial test (pretest) is completed, the two selected classes will be given a different learning model. The first experimental class (32 people) was given an Inquiry learning model and the control class (33 people) was given a conventional learning model.
After the learning activities were completed, the two classes were given a final test (postest) with slightly different questions and an observation sheet in order to determine the increase in science process skills between students who received inquiry and conventional learning models.

\subsubsection{Description of Science Process Skills Data}

The data obtained and analyzed in this study were scores from the observation of science process skills of students who received inquiry and conventional learning. The data collection for science process skills used observation sheets totaling 12 observation items with scoring guidelines 0-3. Data from the research results of observations of science process skills using anova analysis. The following is the data on the results of measuring science process skills from the Inquiry experimental class and the conventional control class.

4.1.2.1 Observation of Science Process Skills

Science process skills data were obtained as follows:

Table 2. Calculation of Total Score, Highest Score, Lowest Score, Average, Standard Deviation, Initial Test Variance

\begin{tabular}{|l|c|c|}
\hline \multirow{2}{*}{ Calculation } & \multicolumn{2}{|c|}{ Class } \\
\cline { 2 - 3 } & Eksperiment & Control \\
\cline { 2 - 3 } & Inkuiry & Conventional \\
\hline Total score & 788 & 734 \\
\hline Highest Score & 34 & 30 \\
\hline Lowest Score & 19 & 15 \\
\hline Average & 25,41 & 22,24 \\
\hline Standard Deviation & 4,76 & 3,95 \\
\hline Variance & 22,71 & 15,62 \\
\hline & & \\
\hline
\end{tabular}

From Table 2 it can be seen that the total score, highest score, lowest score, average, standard deviation, and variance for the two learning classes have all different values, none of which are the same. So to make sure we continue with the normality test, homogeneity and one-way ANOVA, if there is a difference then a further test is carried out.
Based on table 2, it is known that the data frequency of all groups. Before continuing the analysis, it is necessary to know whether this data is normal or not. So it is necessary to test for normality with the One sample Kolmogrov-Smirnov test using SPSS. From the results of the normality test, the following data were obtained:

Table 3.Normality Test (NPar Tests) Results of Science Process Skills

\begin{tabular}{|c|l|c|c|c|c|}
\hline \multirow{2}{*}{ Aspect of Ability } & \multirow{2}{*}{ Group } & \multicolumn{2}{|c|}{ Kolmogrov-Smirnov } & \multirow{2}{*}{ Conclusion } & \multirow{2}{*}{ Ket. } \\
\cline { 3 - 6 } & & Stad. & Sig. & & \\
\hline $\begin{array}{c}\text { Science Process } \\
\text { Skills }\end{array}$ & Inkuiry & 4,766 & 0,280 & Accept $\mathrm{H}_{0}$ & Normal \\
\cline { 2 - 6 } & Conventional & 3,953 & 0,659 & Accept $\mathrm{H}_{0}$ & Normal \\
\hline
\end{tabular}

The criteria for assessing the normality test are:

H0: the population has a normal distribution if the sig value $>0.05$

H1: the population has an abnormal distribution if the sig value $\leq 0.05$
Based on the data above, it can be seen that the value of science process skills is in normal circumstances. After the normality of the data is known, it is necessary to test the homogeneity using Levene. The results of the homogeneity test of science process skills are as follows: 
Table 4. Homogeneity Test of Science Process Skills Results

\begin{tabular}{|c|c|c|c|}
\hline Levene Statistic & df1 & df 2 & Sig. \\
\hline 1.965 & 2 & 92 & .146 \\
\hline
\end{tabular}

The criteria for assessing the Levene test are:

$\mathrm{H} 0$ : the population has the same variance if the sig value $>0.05$

H1: the population has unequal / different variances if the sig value $\leq 0.05$

From Table 4 above, it can be seen that the significance value is 0.146 , this means that it is greater than 0.05 , so we know that the data on the results of science processing skills with inquiry learning, and conventional have homogeneous variances. Based on the analysis of data that is normally distributed and homogeneous, one way Anova test can be continued.

To determine the homogeneity of the two classes, a one-way Anova test was carried out after it was known that the science process skills data were normally distributed and homogeneous, then we need to look at the average difference between inquiry and conventional learning. The following is the ANOVA table of science process skills:

Table 5. One-way Anova Results of Science Process Skills

\begin{tabular}{|l|r|c|r|c|c|c|}
\hline $\begin{array}{l}\text { Sources of } \\
\text { Difference }\end{array}$ & $\begin{array}{c}\text { Sum of } \\
\text { Squares }\end{array}$ & df & $\begin{array}{c}\text { Mean } \\
\text { Squared }\end{array}$ & F & Sig. & \multirow{2}{*}{ Ho } \\
\cline { 1 - 4 } Between groups & 189.152 & 2 & 94,576 & 4,620 & 0,012 & \multirow{2}{*}{ Reject } \\
\cline { 1 - 5 } Inter Group & 1883.480 & 92 & 20,473 & & & \\
\hline Total & 2072.632 & 94 & & & & \\
\hline
\end{tabular}

Judging from the results above, the significance value obtained is 0.012 which is smaller than 0.05. It means that the results of students' science process skills using inquiry and conventional learning models are very significantly different. To find out the differences between treatments, a post hoc test is carried out.

Table 6. Post Hoc Advanced Test of Science Process Skills

\begin{tabular}{|c|l|r|r|c|}
\hline \multicolumn{2}{|c|}{ Class } & \multicolumn{1}{c|}{ Mean Difference } & \multicolumn{1}{c|}{ Sig. } & Ho \\
\hline Inkuiry & Conventional & $2.69306^{*}$ & .019 & Reject \\
\hline Conventional & Inkuiry & $3.17693^{*}$ & .006 & Reject \\
\hline
\end{tabular}

Based on table 6 , it is obtained that the sig value is smaller than 0.05 , which means there is a difference, so it is necessary to continue with the LSD further test to see the difference. From table 6, inquiry and conventional are 0.06. Because the two classes have no very real differences, there is no very good learning model to improve students 'science process skills, conventional inquiry is better for improving students' science process skills in learning plant anatomy.

\subsection{Discussion}

\subsubsection{Science Process Skills in Inquiry and} Conventional Learning Judging from the data that has been obtained, the average for the inquiry class is greater than the conventional class. This approach is very integrated including the application of scientific processes with logical thinking and critical thinking processes. Inquiry is an approach to gaining knowledge and understanding by asking, observing, investigating, analyzing, and evaluating. In learning with the inquiry learning model students see the science process as a skill that they can use to become more curious about, everything in this world sees lecturers as facilitators asking more questions, where the questions are used to develop activities and materials, skilled in proposes cause and effect from observations and is full of pure ideas.

Mastery of science process skills by students will develop students' independent learning ability to see and explore the world, solve problems and seek new understandings [22]. Through process skills, attitudes and values are developed which include curiosity, honesty, patience, openness, nonsuperstition, critical, persevering, tenacious, careful, disciplined, and caring for the environment [23]. Written tests cannot measure work performance, but remains useful for measuring mastery of the knowledge base, including the knowledge base for 
students to display their performance. This is also in accordance with research [24], that the application of guided inquiry has a significant effect on students' science process skills; it is also in accordance with research [25] that the inquiry approach can improve students' science process skills in biology science learning.

The learning material delivered by the teacher tends to be taken for granted without any prior analysis so that the application of low learning independence in learning, the teacher must provide continuous guidance in learning, students will only carry out the learning process according to the instructions given by the teacher. As a result, teachercentered learning models such as conventional learning models are more suitable to be applied to students who have low learning independence. The conventional learning model is a teacher-centered learning model. In the learning process, the teacher has a very important role. Teacher activity is an important concern in the conventional model. This learning model does not provide opportunities for students to take part in the learning process in other words, it does not provide opportunities for students to develop their learning independence. So that the conventional learning model is suitable for students who have low learning independence.

From the results of the analysis, it can be seen that the mean comparison of conventional inquiry learning models is 3.176. So it can be concluded that the improvement of science process skills is better done using inquiry learning models because the effectiveness value is greater than conventional learning models.

Based on the research that has been done, with several articles in similar research journals it can be said that the application of inquiry model learning is good to be applied and used as an alternative to learning biology in universities in improving the quality of student science process skills.

\section{CONCLUSION}

Based on the results of data analysis and discussion, several conclusions can be made:

1. There are differences in the science process skills of students who use inquiry and conventional learning models.

2.Inquiry learning model is an excellent model for improving students' science process skills.

3.Inquiry learning model is a very good learning model when compared to conventional because the two classes of Inquiry learning model and conventional learning alone have no very real differences.

\section{ACKNOWLEDGMENT}

The author would like to thank all those who have helped carry out this research, especially Muhammadiyah University of Bengkulu.

\section{REFERENCES}

[1] Trianto. 2011. Model Pembelajaran Terpadu. Bumi Askara. Jakarta.

[2] Misbah, M., Dewantara, D., Hasan, S. M., \& Annur, S. (2018). The development of student worksheet by using Guided Inquiry Learning Model to train student's scientific attitude. Unnes Science Education Journal, 7(1).

[3] Shoimin, A. (2016) Model pembelajaran Inovatif dalam kurikulum 2013. Yogyakarta: Ar-Ruzz Media.

[4] Irwandi, 2009. Strategi Pembelajaran Biologi Berbasis Kontekstual. Universitas Muhammadiyah Press. Bengkulu.

[5] Mohamad, N dan Uno, H. 2012. Belajar Dengan Pendekatan Pailkem. Bumi Askara. Jakarta

[6] Bundu, P. 2006. Penilaian Keterampilan Proses Dan Sikap Ilmiah Dalam Pembelajaran Sains$S D$. Departemen Pendidikan Nasional Direktorat Jenderal Pendidikan Tinggi Direktorat Ketenagaan. Jakarta.

[7] Tenten, H. 2010 Keterampilan proses sains. Diakses dari : http//biopointtenten. Blogspot.com 2010/08/keterampilan-proseskps. html. 28 Oktober 2020.

[8] Amnah, R., Rauf, A., Rasul, M. S., Mansor, A. N., Othman, Z., \& Lyndon, N. (2017). Inculcation of Science Process Skills in a Science Classroom, 9 (8), 47-57.

[9] Irwandi, 2010. Pengaruh pendekatan kontekstual melalui strategi inkuiri dan masyarakat belajar terhadap hasil belajar kognitif. Jurnal Pendidikan Biologi. Jurusan Biologi FMIPA .Universitas Negeri Malang.

[10] Amir,M. Taufiq. 2009. Inovasi Pendidikan melalui Problem Based Learning. Kencana. Jakarta. 
[11] Abungu, H. E., Okere, M. I., \& Wachanga, S. W. (2014). The effect of science process skills teaching approach on secondary school students' achievement in chemistry in Nyando District, Kenya. Journal of Educational and Social Research, 4(6), 359.

[12] Sugiharto, B. 2011. Membangun Karakter Melalui Pembelajaran Biologi Dengan Pendekatan Keterampilan Proses Sains. Hal 201. Jurnal penelitian mahasiswa. Seminar Nasional FKIP UNS.

[13] Rustaman, N., Dirdjosoemarto, S., Yudianto, S. A., Achmad, Y., Subekti, R., Rochintawati, D., \& Nujhani, M. (2005). Strategi Belajar Mengajar Biologi Malang.UM Press

[14] Setyosari, P. (2017). Menciptakan pembelajaran yang efektif dan berkualitas. JINOTEP (Jurnal Inovasi dan Teknologi Pembelajaran): Kajian dan Riset Dalam Teknologi Pembelajaran, 1(1), 20-30.

[15] Salim, S., Suryaman, S., \& Rusmawati, R. D. (2019). Keefektifan Tingkatan Pembelajaran Inkuiri (Level Of Inquiry) Terhadap Peningkatan Keterampilan Proses Sains Pada Pengetahuan Awal Siswa Yang Berbeda. Edcomtech Jurnal Kajian Teknologi Pendidikan, 4(2), 96-108.

[16] Ergül, R., Şımşeklı, Y., Çaliş, S., Özdılek, Z., Göçmençeleb1, Ş., \& Şanli, M. (2011). THE Effects Of Inquiry-Based Science Teaching On Elementary School Students'science Process Skills And Science Attitudes. Bulgarian Journal of Science \& Education Policy, 5(1).

[17] Purwanto, W. L., \& Hidayat, R. (2013). Analisis Kemampuan Inkuiri dan Hasil Belajar Siswa Sekolah Menengah Pertama melalui Model Pembelajaran berbasis Model Hierarki Of Inquiry. Prosiding Pertemuan Ilmiah XXVII HFI Jateng \& DIY, Solo, 23, 0853-0823.
[18] Ayuningtyas, P. Soegimin, \& Imam, SA (2015). Pengembangan perangkat pembelajaran fisika dengan model inkuiri terbimbing untuk melatihkan keterampilan proses sains siswa pada materi fluida statis. Jurnal Pendidikan Sains Pascasarjana Universitas Negeri Surabaya, 4(2), 638.

[19] Putri, F., Zainuddin, Z., \& Miriam, S. (2019). Meningkatkan Keterampilan Proses Sains Siswa Melalui Model Pembelajaran Inkuiri Terbimbing pada Materi Cahaya. Jurnal Ilmiah Pendidikan Fisika, 3(1), 24-32.

[20] Hendra, Dkk. 2012. Pengaruh Model Pembelajaran Inkuiri Laboratorium Terhadap Keterampilan berpikir kreatif dan Keterampilan Proses Sains Siswa Ditinjau Dari Kemandirian Belajar Siswa. Skripsi Pendidikan Biologi. UNS.

[21] Arikunto, S. (2006). Metodologi penelitian. Yogyakarta: Bina Aksara.

[22] Yasir, S. 2011. Pengaruh Strategi Pembelajaran INSTAD Terhadap Keterampilan proses Sains. Jurnal Penelitian Mahasiswa Pendidikan Biologi UNS.

[23] Rusman. 2011. Model-Model Pembelajaran : Mengembangkan Profesionalisme Guru. Rajawali Press. Jakarta.

[24] Ambarsari, W. (2012). Penerapan pembelajaran inkuiri terbimbing terhadap keterampilan proses sains dasar pada pelajaran biologi siswa kelas VIII SMP Negeri 7 Surakarta.

[25] Nurochman, T. 2008. Pengaruh Pendekatan Inkuiri Terhadap Peningkatan Keterampilan Proses Sains Dalam Proses pembelajaran IPA Biologi. Skripsi Prodi Pendidikan Biologi. Fakultas Sains Dan Teknologi. Universitas Islam Negeri Sunan Kalijaga Yogyakarta. 